\title{
Pillars of Social and Economic Development for Future (KBE-Knowledge Based Economy-HC-Human Capital)
}

\author{
Assoc. Prof. Dr. Fazil Yozgat ${ }^{1}$
}

\begin{abstract}
In this study had been investigated from cognitive ability to economic development in Turkey. Turkey has young population, and developing country. It has candidate member of European Union. It has member of OECD. This means that I compared with OECD countries Pisa examination. I used to EUROSTAT's data EU countries. The main objectives of this study are to compare developing and developed countries population and education system for economic and social development.

Literature review, there are several papers and research human capital and economic development. We should be investigating multidisciplinary approach. Because it is differ from social, cultural, economic and political level. Bologna progress is obliged to regulate for member to EU.

Research Methodology, in this study welfare level and GDP is dependent variable. Enrollment, student, education programs, population, employment, IQ tests and Pisa scores are independent variables. There is positive correlation individual and cognitive skill to human and social capital. But there is cultural and social effect for measurement. I find that high average scores are strongly associated with increases in school enrollments and large reductions in the unemployment.

Data, I used official statistical data fort this paper. United Nations, OECD, EURESTAT, and World Banks data had been used also. Enrollments by educational institution 2014-2015 in Turkey, Preschool, enrollment student are 1156661, Primary school students are, 5434150, Junior high school students are 5278107, General high school, students are 2902954, Vocational and technical high school students are 2788117. Higher educational institutions students are 5139468 (2013-2014). Total enrollment student are 22715465. Classical method and programs is insufficient for in the World. Globalization, unemployment and for job ability requires new paradigm. I investigated and compared with these subjects.
\end{abstract}

Key words: Conclusion and advice, "21st century skills", "career readiness", "next generation learning", "new basic skills", "higher order learning " requires new program paradigm for Turkey.

\section{Introduction}

There is a general consensus that Human Capital is a major determinant of economic development. However, the range of available Human Capital variable is very wide in technical and theoretical senses that different Human capital measurement is sometimes only comment.

Economy is a social science. Therefore in this study dependent variable is social development, independent variables are, forms of capital and subfield social sciences. This paper focuses on essence and relationship as a human capital instrument and pillars social and economic development. Main objective is to denominate to literature and 
conceptual framework human capital measurement and its important education system. Because today world society called information society, post modern society, some scholars. Those are

Drucker,Castells,Lundvall,Foray,Fukuyama,Vorian,Karvoliç,Schumpeter,Arrow,Stixler,R omer,Stiglitz,Backer,Bourdieu,Coleman, Waquant. There are some institutions those are EU, IMF, OECD, WB, UNECSO. In today world society classical class imagine absolutely changed. Marx's class analysis not enough explain to today's real society. Class context means changed. Instead of class level, we should look at as concepts. Those are; revenue level, skills, ability, non ability, heredity, social status, workforce, forms of capital.

Social Structure is another pillar social and economic development. Economy especially political economy includes general argument and paradigm. But social structure is differing from ether. Therefore policymaker and academic administer should be struggle to regulate for future.

Planned economy is reality. But classical planned economy not enough explain for market economy. France and The Netherlands is good example new planned economy. Former Russia and former Yugoslavia nor achieve economic problem. Classical sector which is labeled industry, agriculture and service but today form of sector increased and requires new ability and skill. For example, those sectors are Tourism, Innovation, Knowledge, Marketing ext. Therefore human capital and knowledge based economy should be priority this field.

Social and cultural capital including intangible capital has prior to using. This means that educated, and skilled person is effects workforce and reducing illegal economy, shadow economy, Norway, New Zealand and Australia are good example this using capitals.

Turkey has 193 university in 2016.Turkey universities has enrollment student are 6.785.535, lecture staff number are 68.352, academic staff number are 148.9033 this mechanism associated with cognitive ability, educated staff. This educated and skilled person effects GDP.GDP and human and economic development is dependent variables, Independent variables are, skilled person, R\&D expenditure, innovation, IT and competiveness.

Classical economy and classical capital logic had been chanced. There are a lot of forms of capital those explained above. In 21 century nation of wealth is depends on forms of capital and capital using. Cognitive ability and non cognitive ability is differing from the others. Eduction system and enrollment sub system should be regulate for events' agreement and strategy is good example this matter. Dependent variables is economic and social development, independent variables are form of capital, especially human capital. Turkey has young population and workforce. Therefore human capital and cognitive ability are effects economic development. OECD survey data's supports my hypothesis.

\section{Literature Review:}

\section{Public Expenditure On Education As \% Of Total Government Expenditure}

Definition: Total public expenditure on education (current and capital) expressed as a percentage of total government expenditure in a given financial year. 
Purpose: To assess a government's policy emphasis on education relative to the perceived value of other public investments. It reflects also the commitment of a government to invest in human capital development. Calculation method: Divide total public expenditure on education incurred by all government agencies/departments in a given financial year by the total government expenditure for the same financial year and multiply by 100 .

Formula:

PXEt
\%PXE:-
TPXt
T

Where :

\%PXEt: Public expenditure on education as a percentage of total government expenditure in financial year $\mathrm{t}$

PXEt: Total public expenditure on education in financial year $\mathrm{t}$

TPXt: Total government expenditure in financial year $\mathrm{t}$

Data required: Total public expenditure on education; and total government expenditure.

Data sources: Annual financial reports prepared by the ministry of finance; national accounts reports by the central statistical office and financial reports from the various government departments engaged in education activities especially the ministry of education. Data disaggregation: By level of administration, geographical location (region, urban/rural), and by purpose of expenditure (emoluments, teaching material, etc.).Interpretation: A higher percentage of government expenditure on education shows a high government policy priority for education relative to the perceived value of other public investments, including defense and security, health care, social security for unemployment and elderly, and other social or economic sectors. Quality standards: Total public expenditure on education should include those incurred by all concerned ministries and levels of administration. This indicator can never be $100 \%$ since the latter includes expenditure on many economic and social sectors, besides education. The fact that the fiscal year and educational year budget periods maybe different should also be taken into consideration. Limitations: In some instances data on total public expenditure on education refers only to the ministry of education, excluding other ministries that spend a part of their budget on educational activities.(Unesco,2009:p.21)

Economic and social theories are set of knowledge. Science is connected with reason and results. In several economic theories argues that the value of education is evaluated by way of two different theoretical approaches; the human the capital approach and human capabilities, which are including cognitive and non cognitive approach.

Schooling period are both relevant and espouse for children. Cognitive ability develops fort his period, non cognitive ability established this period. This means that, Turkish education enrollment must be regulate knowledge based economy and form of capitals. Human capital measures different ways, but effects of capital measures TIMSS (Trends in International mathematics and Science Study) and PISA.(Program of International Student Assessments), this program especially using by OECD countries' Turkey increases for PISA score, GNP effect will be increase absolutely. This hypothesis supports some evidence fellow. 
There are several forms of capitals. This capital is affecting others. Dependent variables are another capitals independent variables' summarized form of capitals investigated human capital analytically.

Form of capital Pillars

A. Development Capital. Innovation-patent-

B. Market Capital

C. Process Capital

D. Structural Capital.

E. Intellectual Capital

F. Relational Capital.

G. Human Capital.

H. Social Capital.

I. Intellectual Capital.

J. Religion Capital.

K. Fiscal Capital

L. Natural Capital

M .Cultural Capital.

N. Intangible Capital.

O. Spiritual Capital.

Ethic-culture

Skilled staff

Trust-well-being -

Values, Trust, arts
Brand-Vision-intangible assets

Institution structure-expert staff

System-sub system-Strategy

Distributors- Costumer-Business

Knowledge-cognitive ability

Education, workforce, skilled person

Trust-net work-culture, NGOs

Knowledge-productivity

GDP-GNP-Tangible assets, Stocks

Natural resources, Land, Environment

Investment, R\&D, IT, Competitiveness State and Private sector

Religion, values, attitude
Effect area

Organization-State R\&D area

Organization-private R\&D area

Business area

State and private sector

State and private sector

State and private sector

16-64 age persons

All citizen, GO s

Enrollment student-

All citizens

State and private sectors

All citizen

All Citizen

I investigated only human capital compared with some measurement Human capital. I found that the best important capital is human capital. Human capital is direct effect GDP for country. Therefore Turkey has young population and a lot of capitals. Turkey should be change from primary school to doctoral level programs. Turkey should be increase PISA scores for development .In sum up social and economic change, globalization, innovation, R\&D are independent variables GDP, GNP and well-being and welfare state are dependent variables. Human Capital and other form of capital should be investigated for apply Turkish education system. This is labeled multiple affect. For example if Human capital applies shadow economy will be reduced. Shadow economy economic activities and reel income denied from that circumvent or avoid government regulation or taxation. There is positive correlation human capital and cultural capital result with shadow economy. There is some research this matter ,USA,EU, and Australia particularly Japan and South Korea have shadow economy are little level, whereas Bulgaria, Romania, Latvia, Afghanistan has highest shadow economy.

The term knowledge-based economy stems from a fuller recognition of the role of knowledge and technology in economic growth. Several characteristics define a knowledge-based economy: (1) it is focused on intangible resources rather than tangible resources [Edvinsson and Malone, 1997]; (2) it has a very powerful technological driving force; i.e., the rapid growth of information technologies (IT); (3) it is stimulated by the rapid growth of ITs with telecommunication and networking, which have penetrated all spheres of human activity, forcing the ITs to work in a new mode and creating new spheres; and (4) knowledge has become an independent force and the most decisive 
factor in social, economic, technological, and cultural transformation [UNECE, 2002) (1 Safdari Mehdi, 2 Motiee Reza ,2012 p.2397)

Knowledge based economy is different from other type of economy. Knowledge based economy reveals a new role and place of modern society. Knowledge, innovation, R\&D, recognized the decisive factors of economic and social development, those using as a instruments competition and skilled person.

The importance of skills development in today's knowledge economy is undeniable. Skills development is a crucial factor and determinant of human capital accumulation, labor productivity, poverty reduction, and growth. It is a comprehensive and crosssectoral issue that continues to occupy the agendas of both the education and labor market arenas, as well the public and private sectors in both developed and developing nations alike. However, it is this comprehensiveness that lends immense difficulty in conclusively determining how skills development is actually linked to the abovementioned factors such as, employment and growth.(Yoo Jeung, Joy Nam,2009 p.1)

\section{Comparative analysis:}

Mean years of schooling (MYS) have been used by the Human Development Report Office(HDRO) of the United Nations Development Programme (UNDP) since 2010 as one of two education indicators in the calculation of the Human Development Index (HDI) (UNDP, 2010).MYS replaced the adult literacy rate that was used in the calculation of the HDI until 2009(UNDP, 2009). The second education indicator used in the calculation of the HDI is the school life expectancy, called "expected years of schooling" by HDRO, which replaced the combined gross enrolment ratios in primary, secondary and tertiary education.(UNECSO,2013 p.1)

The method for the calculation of MYS used at the UIS is similar to the approach by Barro and Lee (1993, 2010). The following information, available in the education statistics database of the UIS, is needed for each country to estimate MYS: Distribution of the population by age group and highest level of education attained in a given year; and Time series with the official duration of each level of education. For each age group, the proportion that attained a given level of education is multiplied by the official duration of that level. The sum of the resulting values yields the MYS for the population under investigation. For example, assume that $50 \%$ of a population completed primary education with a duration of 4 years, and 50\% completed lower secondary education with a duration of 4 years, which means they spent 8 years in primary and lower secondary education combined. In this case, MYS is $0.5 \times 4+0.5 \times 8=6$ years.(Unesco,2013,p.4)

The Commission proposes increasing the amount allocated to R\&D and innovation from S55 billion in the last financial framework to S80 billion in 2014-20.This is welcome but still inadequate for a continent whose future prosperity will depend on staying at the technological frontier.. (John Peet and Stephen Tindale, 2012; p.6).South Korea leads 2013 R\&D expenditure GDP ratio among advances nations.

Postsecondary VET in Korea In Korea most young people enter high school (88.5\% of15-19-year-olds in 2008 (OECD, 2011a), either general (75.5\%), vocational $(23.5 \%)$ or other types $(1 \%)$. Both types of high school allow students to pursue post secondary 
studies. In $200985 \%$ of general high school graduates sand $74 \%$ of vocational high school graduates enrolled in a post secondary programme (MEST, 2010). Access to post secondary education is selective and students are admitted to an institution and programme based on their performance on the Korean Scholastic Aptitude Test (KSAT).Posts secondary VET accounts for $30.8 \%$ of tertiary enrolment (Kim,Woo, Ryu and Oh, 2011). It is provided by two types of institution: junior colleges and polytechnics. The junior college sector is much larger, enrolling over 50 times more students than polytechnics. Access to junior colleges is selective in principle, but not genuinely so in some institutions that struggle to fill their places. About two thirds of entrants are recent high school graduates, while most of the rest are students who retook the KSAT test.( Kis, V. and E. Park (2012,p.15)

The well qualified labor forces are an indispensable component for a productive economy. This means that has been the well qualified labor force is possible with well planned high school vocational and technical education. In this view, vocational and technical education is critically important for the developing economies. Turkey needs to well qualify labor force to employ in its own industry.

Define the set of key skills that are referenced by the labels "deeper learning," "21st century skills," "college and career readiness," "student centered learning," "next generation learning," "new basic skills," and "higher order thinking." These labels are typically used to include both cognitive and no cognitive skills-such as critical thinking, problem solving, collaboration, effective communication, motivation, persistence, and learning to learn that can be demonstrated within core academic content areas and that are important to success in education, work, and other areas of adult responsibility. The labels are also sometimes used to include other important capacities—such as creativity, innovation, and ethics - that are important to later success and may also be developed in formal or informal learning environment. (James W. Pellegrino and Margaret L. Hilton, p.14)

Technical education: theoretical vocational preparation of students for jobs involving applied science and modern technology; compared to vocation education (which focuses on the actual attainment of proficiency in manual skills), technical education emphasizes the understanding of basic principles of science and mathematics and their practical applications; usually delivered at upper-secondary and lower-tertiary levels to prepare students for occupations that are classified above the skilled crafts but below the scientific or engineering professions (although diploma- and degree-level courses also exist).

Vocational education: organized activities designed to bring about learning as preparation for jobs in designated (manual or practical) trades or occupations; traditionally nontheoretical and focused on the actual attainment of proficiency in manual skills; usually considered part of the formal education system and thereby falling under the responsibility of the Ministry/Department of Education.

Vocational training: prepares learners for jobs that are related to a specific trade or occupation; but, compared to vocational education, is better linked to the labor market and employment development system, and therefore usually falls under the responsibility of the Ministry/ Department of Labor. On-the-job training: workplace-based training that uses real jobs as a basis for instruction and for practical purposes. Apprenticeship 
training: combines on-the-job training for a highly skilled craft or trade (from someone who is already a skilled leader in the field) with academic/ theoretical instruction; also called dual-training programmes.( Janice Tripney, p.3)

Education system from primary school to PhD level is foundation human capital a country. Which is process is contribute economic development. Vocational training especially developing countries are very important education level. Germany, Japan, and USA are good examples this system. Vocational and Technical high schools those schools are provided specialized instruction with the aim of training qualified personnel. These personnel will be employ public and private sectors. Market economy and social and economic change requires qualified skilled persons.

Knowledge based economy established technology transfer and adopted from donor countries to receive country, to protect intellectual property right, and lastly skilled staff contributed to workforce. Private sectors have been expenditure R\&D but this matter differs from company to company. Human capital indicator is changing for measurement. Mainly human developments index are (HDI, Human Development Index, CER, Combined Enrollment Ratio, EII, Education Index, LEI, Life Expectancy, WBE, Well being Index, NRI, Networked Readiness Index, KEI ,Knowledge economy Index, SII ,Summary Innovation Index. )

Education is provided from the beginning to the end of compulsory schooling, with no transition between primary and lower secondary education, and with general education provided in common for all pupils. After successful completion of primary education, students are required to follow distinct educational pathways or specific types of schooling, either at the beginning or during lower secondary education. (European commission, 2014-2015,p.5)

Beyond technical skills, there is evidence that cognitive and non-cognitive skills affect labor market outcomes (Heckman, Stixrud, and Urzua (2006)) Cognitive skills: "ability to understand complex ideas, to adapt effectively to the environment, to learn from experience, to engage in various forms of reasoning, to overcome obstacles by taking thought" American Psychological Association (APA) Literacy Numeracy Ability to solve abstract problems Non-cognitive skills: characteristics across multiple domains (social, emotional, personality, behaviors, attitudes, etc.) not included under cognitive skills Work habits (effort, discipline, determination)Behavioral traits (self-confidence, sociability, emotional stability )Physical characteristics (strength, dexterity, endurance)Technical skills: Combinations of cognitive and non-cognitive skills used to accomplish specific tasks.

Table:1

Effect on GDP of Scenario I:

Increase average performance by 25 points on PISA, or by $1 / 4$ standard deviation Value of reform (USD bn)

Australia

Austria

Belgium

Canada

Czech Republic

Switzerland
2527

899

1108

3743

918

792 


$\begin{array}{lr}\text { Germany } & 8088 \\ \text { Denmark } & 586 \\ \text { Spain } & 4147 \\ \text { Finland } & 553 \\ \text { France } & 6043 \\ \text { United Kingdom } & 6374 \\ \text { Greece } & 996 \\ \text { Hungary } & 587 \\ \text { Ireland } & 514 \\ \text { Iceland } & 40 \\ \text { Italy } & 5223 \\ \text { Japan } & 11640 \\ \text { Korea } & 4054 \\ \text { Luxembourg } & 116 \\ \text { Mexico } & 4812 \\ \text { Netherlands } & 1889 \\ \text { Norway } & 841 \\ \text { New Zealand } & 338 \\ \text { Poland } & 2029 \\ \text { Portugal } & 680 \\ \text { Slovak Republic } & 311 \\ \text { Sweden } & 1019 \\ \text { Turkey } & 3416 \\ \text { United States } & 40647 \\ \text { OECD } & \mathbf{1 1 4} 930\end{array}$

Notes: Discounted value of future increases in GDP until 2090, expressed in billion USD (PPP). For reform parameters, (OECD, 2010, p.23)

Table:II.Effect on GDP of Scenario II.Bring each country to Finish level of 546 points on PISA. Value of reform (USD $\%$ of current GDP Long-run growth increase Increase in PISA score

(Percentage points)

$\begin{array}{lrrrr}\text { Slovak Republic } & 709 & 609 \% & 0.92 & 52.9 \\ \text { Sweden } & 1657 & 435 \% & 0.68 & 39.2 \\ \text { Turkey } & 21365 & 1673 \% & 2.08 & 120.1 \\ \text { United States } & 103073 & \mathbf{6 7 8 \%} & 1.01 & 58.1 \\ \text { OECD } & \mathbf{2 6 0} \mathbf{2 0 4} & \mathbf{6 0 6 \%} & \mathbf{0 . 8 7} & \mathbf{4 9 . 8}\end{array}$

Table 2 Effect on GDP of Scenario II: Bring each country to Finish level of 546 points on PISA

Notes: Discounted value of future increases in GDP until 2090, expressed in billion USD (PPP) and as percentage of current GDP.-"Long-run growth increase" refers to increase in annual growth rate (in percentage points) once the whole labour force has reached higher level of educational performance. "Increase in PISA score" refers to the ultimate increase in educational performance due to the reform (of bringing each country to the Finish average level of 546 PISA points on the 2000 reading scale).(OECD,2010.p.24)*Turkey the most score 30 countries. This data support my hypothesis. (Summarized by Authors.) 


\section{Table.III.Effect on GDP of Scenario III.Bring all minimum of 400 points on PISA. \\ Value of reform (USD bn \% of current GDP Long-run growth increase Share of students below (Percentage points) minimum skill}

$\begin{array}{lcccc}\text { Portugal } & 1545 & 608 \% & 0.92 & 24.2 \% \\ \text { Slovak Republic } & 450 & 387 \% & 0.61 & 16.2 \% \\ \text { Sweden } & 1205 & 316 \% & 0.51 & 13.4 \% \\ \text { Turkey } & 14895 & 1167 \% & 1.58 & 41.8 \% \\ \text { United States } & 72101 & 475 \% & 0.74 & 19.4 \% \\ \text { OECD } & 193301 & 450 \% & 0.68 & 18.0 \%\end{array}$

Notes: Discounted value of future increases in GDP until 2090, expressed in billion USD (PPP) and as percentage of current GDP. "Long run growth increase" refers to increase in annual growth rate (in percentage points) once the whole labour force has reached higher level of educational performance. "Share of students below minimum skills" refers to the share of students in each country performing below the minimum skill level of 400 PISA points.(OECD,2010,p.26).Summarized by Authors.

According to Zelanzny, who is made empirical research result, supported my hypothesis. As seen in below if new paradigm and new programs in Turkish education system, workforce and GDP will be absolutely increases' sum up there is positive correlation new teaching technique and knowledge based education system with social and economic development.

IDI, NRI, KEI and SII values in selected countries in 2002.(Summarized by author)

Table: IV.

Country

Information Society

IDI $2012 \quad$ NRI 2012

Knowledge economy

Sweden

8.45

5.94

4.64

4.07

8.35

5.16

SII 2102

(Resource: Zelanzy; 2015, p.17)

Economies are extremely as forms of employment. Employment's essence is workforce.Workforse2s pillar is skilled persons. In USA R\&D expenditure is rising from 3.4 billion USA dollars to 515 billion USA dollars. China R\&D expenditure is rising increases from 6.3 billion US dollars to 396 billion dollars.

\section{Human Capital measurement:}

${ }_{\mathrm{a}} h_{e, a}=w_{1, a}^{e} y_{1, a}^{e}+w_{2, a}^{e} y_{2, a}^{e}+s r_{a, a+1} h_{e, a+1}(1+g) /(1+r)$

(Source:Gu and Wong;2010,p.13)

$h_{e, a}: 2000-$

$$
h_{e, a=} \text { ? }
$$

e;3

a;22-70

$w_{1, a}^{e}:{ }_{1000 ; 3}$ 
$y_{1, a}^{e}:{ }_{11000 ; 3}$
$w_{2, a}^{e}:{ }_{2000 ; 3}$
$y_{2, a}^{e}:{ }_{800 ; 3}$
$s r_{a, a+1}:{ }_{6}$
$h_{e, a+1}:{ }_{2000}$
$g:{ }_{5}$
$r: 0.8$
$e=$ educational attainment levels $(1$ to 5$): 1$ = zero to eight years of school, $2=$ some or
completed high school, $3=$ some post-secondary education below bachelor's degree, $4=$
bachelor's degree, $5=$ master's degree or above; $a=$ ages: 15 to 74 ;

$h_{e, a}=$ average human capital or average lifetime labour income per capita for individuals with age (a) and education level (e);

$w_{1, a}^{e}=$ probability of engaging in paid employment for individuals with age $(a)$ and education level (e), defined as the number of paid workers over the population for that cohort;

$y_{1, a}^{e}=$ annual labour compensation of paid workers with age $(a)$ and education level $(e)$;

$w_{2, a}^{e}=$ probability of engaging in self-employment for individuals with age $(a)$ and education

level (e), defined as the number of self-employed workers over the population for that cohort;

$y_{2, a}^{e}=$ annual labour compensation of self-employed workers with age $(a)$ and education level $(e)$;

$s r_{a, a+1}=$ the probability of surviving one more year from age $(a)$; and

$g=$ real income growth rate;

$r=$ discount rate.

$$
H_{c}=\sum_{t=0}^{p} C_{t}(1+i-d)^{p-t}
$$

(Source: Adolf Stroombergen,Dennis Rose Ganesh Nana.2002,p.8)

$$
\begin{aligned}
& H_{c}: ? \\
& C:{ }_{20000} \\
& i: 0.9 \\
& d:{ }_{0.4} \\
& p:{ }_{1}
\end{aligned}
$$

$H_{c}=$ Human capital defined from investment costs

$C=$ Investment costs, including direct and opportunity costs

$i=$ interest rate

$d=$ depreciation rate

$p=$ the present

$$
\begin{aligned}
& \sum_{t=1}^{s}\left(C_{h, t}+W_{l, t}\right)(1+r)^{t}=\sum_{t=s+1}^{A_{h}}\left(W_{h, t}-W_{l, t}\right)(1+r)^{-t} \\
& \sum_{t=1}^{s}\left(C_{h, t}+W_{l, t}\right)(1+r)^{t}=\sum_{t=s+1}^{A_{h}}\left(W_{h, t}-W_{l, t}\right)(1+r)^{-t}=3380
\end{aligned}
$$


(Source: Adolf Stroombergen,Dennis Rose Ganesh Nana.2002,p.8)

$C_{h}: 25000$

$W_{l}: 100$

$W_{h, t}-W_{l, t}: 2000$

$S: 4$

$A_{h}: 55$

$C_{h}=$ the resource cost of schooling incurred to achieve a higher level $b$ from a lower level $l$,

$W_{l}=$ the foregone earnings of the student while studying

$\left(W_{h, t}-W_{l, t}\right)=$ the earnings differential between a person with a higher level of education and a person with a lower level of education

$s=$ years of schooling

$A_{h}=$ the highest possible working age.

$H C=W_{A T}\left[\frac{1-\frac{1}{(1+i)^{n}}}{i}\right]$

(Source:Kenneth M. Washer and Srinivas Nippani,2004,p.16)

$H C:$ ?

$W_{A T}: 3000$

$n: 33$

$i: 0.8$

$\mathrm{HC}=$ estimated present value of human

Capital

$W_{A T}=$ current net after tax cash flow adjusted

for personal consumption

$\mathrm{n}=$ expected number of remaining working

years

$\mathrm{i}=$ inflation and risk adjusted discount rate

$H_{e}=\sum_{t=p}^{n} \frac{E_{t}+B_{t}}{(1+i)^{t-p}}$

(Source: Adolf Stroombergen,Dennis Rose Ganesh Nana.2002,p.8)

$H_{e}:$ ?

$E: 3000$

$B: 300$

$i: 0.9$

$p:{ }_{1}$

$t: 6$

$H_{e}=$ Human capital defined from earnings and other benefits 
$E=$ Earnings (often expressed as the difference between actual earnings and a basic, unskilled, wage rate)

$B=$ other (non-market) benefits derived from increased human capital

$i=$ interest rate

$p=$ the present

$t=$ time

$$
h_{e, a}=w_{1, a}^{e} y_{1, a}^{e}+w_{2, a}^{e} y_{2, a}^{e}+s r_{a, a+1} h_{e, a+1}(1+g) /(1+r)
$$

\begin{tabular}{|c|c|c|c|c|c|c|c|l|}
\hline$h_{e, a}$ & $w_{1, a}^{e}$ & $y_{1, a}^{e}$ & $w_{2, a}^{e}$ & $y_{2, a}^{e}$ & $s r_{a, a+1}$ & $h_{e, a+1}$ & $\mathrm{~g}$ & $\mathrm{r}$ \\
\hline 12.640 .000 & 1000 & 11000 & 200 & 800 & 6 & 2000 & 5 & 0.8 \\
\hline & $H_{c}=\sum_{t=0}^{p} C_{t}(1+i-d)^{p-t}$ \\
$3000_{c}=\sum_{t=0}^{p} 2000_{t}(1+0,9-0,4)^{p-t}$ & $\mathrm{p}$ & $\mathrm{t}$ \\
\hline$H_{c}$ & $\sum_{t=0}^{p} C_{t}$ & $\mathrm{i}$ & $\mathrm{d}$ & 1 & \\
\hline 3000 & 2000 & 0,9 & 0,4 & 1 & 0 \\
\hline
\end{tabular}

$$
\begin{gathered}
\sum_{t=1}^{s}\left(C_{h, t}+W_{l, t}\right)(1+r)^{t}=\sum_{t=s+1}^{A_{h}}\left(W_{h, t}-W_{l, t}\right)(1+r)^{-t} \\
\sum_{t=1}^{s}\left(25.000_{h, t}+100_{l, t}\right)(1+r)^{t}=\sum_{t=s+1}^{A_{h}}(2.000)(1+r)^{-t}=3380
\end{gathered}
$$

\begin{tabular}{|c|l|l|l|l|l|l|l|}
\hline$\sum_{t=1}^{s}\left(C_{h, t}+W_{l, t}\right)(1+r)^{t}=\sum_{t=s+1}^{A_{h}}\left(W_{h, t}-W_{l, t}\right)(1+r)^{-t}$ & $C_{h, t}$ & $W_{l, t}$ & $S$ & $A_{h}$ & $\mathrm{r}$ & $-\mathrm{t}$ \\
\hline 3380 & 25000 & 100 & 4 & 55 & 0,3 & -2 \\
\hline
\end{tabular}

$$
\begin{gathered}
H C=W_{A T}\left[\frac{1-\frac{1}{(1+i)^{n}}}{i}\right] \\
3107=3000_{A T}\left[\frac{1-\frac{1}{(1+0,8)^{33}}}{0,8}\right]
\end{gathered}
$$




\begin{tabular}{|c|c|c|c|c|c|c|}
\hline $\mathrm{HC}$ & \multicolumn{2}{|l|}{$W_{A T}$} & i & \multicolumn{2}{|l|}{$\mathrm{n}$} & \\
\hline 3107 & 3000 & 0,8 & & 33 & & \\
\hline$H_{e}=\sum_{t=}^{r}$ & & & & & & \\
\hline 133.27 & $\frac{000_{t}+300}{(1+0,9)^{6-1}}$ & & & & & \\
\hline$H_{e}$ & $E_{t}$ & $B_{t}$ & $\mathrm{i}$ & & $\mathrm{t}$ & $\mathrm{p}$ \\
\hline 133.27 & 3000 & 300 & 0,9 & & 6 & 1 \\
\hline
\end{tabular}

I applied five human capital measurement methods. Results are above. In sum up that method correct analytical method, but if data's differ forms result can be changed. Human capital measurement can be from country to country, from period to period, from social structure to social structure. Therefore social and economic developments pillars are knowledge based economy, human capital and share of GDP.

Both developed and developing in addition to under developing countries are faced with the demands economic growth and social development in globally competitive world. Main independent variables are,1.information techonology,2.innovation,3.information,4.kno-wledge based economy,5.trade liberelisation,6.social and political change,7.skilled workforce, 8.young population,9.enrollment stdent,10.number of R\&D staff,(full-time)11.Number of R\&D staff private sectors,12.percantege for $\mathrm{R} \& \mathrm{D}$ in GDP,13.Percantege expenditure education on GDP.14.trade liberalization and taxes system.15.regional trade policy.

Economic and Social development are complex phenomenon and they are challenge for researchers to create one index, so there are several indicators, we should not be ignored those indicators.

According to EU criteria and Lisbon strategy is since the adoption of the Lisbon Strategy, transition towards a knowledge economy has become a pivotal policy area for the EU. Turkey has candidate member of EU. Therefore Lisbon criteria are prior to education policy for Turkey.

R\&D is a process. R\&D expenditure of $\%$ GDP costs varies from several fields. This expenditure varies from industry and sectors to industry and sectors. This cost is differing from country to country. This cost changes from year to year. In Turkey this costs resources are founds, universities, TUBITAK, TUBA, business sector, Ministry of Education, Higher Education Council

Among OECD countries, the United States is the main performer with $42 \%$ of the total OECD GERD in 2009, followed by Japan (15\%) and Germany (9\%). Since 1999, real $\mathrm{R} \& \mathrm{D}$ expenditure has been growing the fastest in Estonia, Korea, Portugal and Turkey, with average annual growth rates around 10\%. Outside the OECD area, China's average annual real growth in R\&D spending has been close to $20 \%$, making it the world's second largest R\&D performer and ahead of Japan since 2009. 
Table:V.Gross domestic expenditure on R\&DMillion US dollars - 2005 constant prices and PPPs 1999

2009

$\begin{array}{lcc}\text { Turkey } & 2739 & 7110 \\ \text { United Kingdom } & 29856 & 36731 \\ \text { United States } & 282775 & 365994 \\ \text { EU27 } & 197094 & 262780 \\ \text { OECD } & 650059 & 873833 \text {. (OECD: 2012; p.34) }\end{array}$

I investigated three main questions; those; Restructuring of vocational and higher education is one of the liveliest debated topics in Turkey education system. How should the state and waqf universities system be re organized? How should be increase skilled workforce, how should be vocational training and university programs adopted new competiveness economy? How should be catch up Turkey social and economic aspect developed countries?

The importance of human capital (general and specific) as pillars of progress and economic growth and social development has long been recognized in the several economic literatures last four decade.

"In principle it is easy to accept the idea that universal education is one of the key "Information Technologies upon which western industrial growth has been built. Sweden spends about 6 percent of total labor input one education and research, as measured in the national accounts and the U .S. more than 8 percent. The figure is lower for (Eliasson et.el:1990,p.26)"

Same scholar argued that human capital and education level and economic development those are.:Kyriacou (1991) Lau, Jamison and Louat (1991), and Lau, Bhalla andLouat (1991 ),Barro and Lee (B\&L 1993), Nehru, Swanson and Dubey (NSD, 1995),

If a nation has human capital endowment including the skills, cognitive and non cognitive ability that reside in people and that are put to productive use can be a more important determinant of its should have be long term economic success than virtually any other revenues.

Human capital measurement can be measures different methods, but this methods should be include some pillars and independent variables those are education system, primary-secondary-vocational training-higher education .health and well being, which are mental and physical wellbeing. Workforce, skilled workforces especially median age and lastly protect to environment.

Knowledge based economy and technology are the heart and mind of the comparative economy. The countries struggle that encourage their student and education staff to develop the skills, talent and competencies they need to become better, public staff, business staff, workers, business managers, public administers, young entrepreneurs, and innovators

The French scholar Piketty's book Capital analyzes last two decade economic and social development analyzed in chapter. According to Piketty the state should be protect taxes. "Some economists, including the authors of a recent series of World Bank reports on "the wealth of nations," choose to calculate the total value of "human capital" by capitalizing the value of the income flow from labor on the basis of a more or less arbitrary annual rate of return (typically 4-5 percent). These reports conclude with 
amazement that human capital is the leading form of capital in the enchanted world of the twenty-first century." (Piketty,2014;p.168)

TableVI. $\quad$ R\&D expenditure ( $\%$ of GDP)

\begin{tabular}{lccc} 
Counrty & 2011 & 2012 & 2013 \\
\hline Turkey & 0.80 & 0.92 & 0.94 \\
England & 1.69 & 1.63 & 1.63 \\
USA & 2.77 & 2.81 & - \\
Norway & 1.63 & 1.62 & 1.66 \\
Mongolia & 0.40 & 0.42 & 0.35 \\
Luxembourg & 1.41 & 1.16 & 1.16 \\
Japan & 3.38 & 3.34 & 3.47 \\
Israel & 4.10 & 4.25 & 4.21 \\
Finland & 3.36 & 3.42 & 3.31 \\
Egypt & 0.52 & 0.54 & 0.68 \\
Belarus & 0.04 & 0.04 & 0.04 \\
Armenia & 0.27 & 0.25 & 0.24
\end{tabular}

(Resource.www.worldbank.org. database, 0505.2016.selected countries by Authors)

As seen in table R\&D expenditure \% of GDP correlation has between economic and social development absolutely .In addition to there is multiple effect. This means that county $\mathrm{x}$ has $\% \mathrm{x} 1$, another country $\mathrm{x} 2$ has $\% \mathrm{x} 1$, if country $\mathrm{x} 2$ has GDP rather than country $\mathrm{x} 1$, therefore country $\mathrm{x}$ will be gain multiple effect. Because country $\mathrm{x}$ has GDP bigger GDP than others.

Knowledge based economy and Human capitals are pillars of economic and social development, $R \& D$ expenditure and education programs are instrument for this aims. Because R\& D covers three sub system. Those are A. Basic research B. applied research. C. Experimental research. Types of research can b e change from country to country.

TableVII. Scientific research \& development spending, 2013

$\begin{array}{lll} & 2000 & 2013 \\ \text { World } & \sim \$ 710 \text { billion } \sim \$ 1,700 \text { billion } \\ \text { U.S. } & \$ 269 \text { billion } & \sim \$ 470 \text { billion } \\ \text { EU (28) } & \$ 184 \text { billion } & \$ 345 \text { billion } \\ \text { China } & \$ 33 \text { billion } & \$ 336 \text { billion } \\ \text { Japan } & \$ 99 \text { billion } & \$ 160 \text { billion } \\ \text { All other } ~ & 120 \text { billion } & \sim \$ 390 \text { billion }\end{array}$

* Figures from OECD and National Science Foundation. The 2013 figure for the U.S. is an estimate based on OECD's overall calculation, as the U.S. has not yet published a final 2013 result. EU figures for 2000 include all 28 current members, including the Central and Eastern European states joining in after 2004

\section{Conclusion:}

Social and economic change is reality. Education and workforce system are indisputable general social system. Turkey has young population and forms of capital. Primary, secondary, vocational training and universities should be adopted knowledge based economy and prior to human capital. For example universities can be begun three 
semester period. Secondary school and vocational schools programmers can be innovations and competiveness and market economy

\section{References}

Adolf Stroombergen, Dennis Rose, Ganesh Nana; Review of the Statistical Measurement of Human Capital, Info Metrics Consulting , Business and Economic Research Ltd.2002. Gylnar Eliasson and et.al. Knowledge Based Information Economy

The Industrial Institute Economic and Social Research, Stockholm 1990. James J. Heckman, Jora Stixrud, Sergio Urzua, "The Effects of Cognitive and Noncognitive Abilities on Labor Market Outcomes and Social Behavior," Journal of Labor Economics, 2006, vol. 24, no. 3]

James W. Pellegrino and Margaret L. Hilton." Committee on Defining Deeper Learning and 21st Century Skills; Center for Education; Division on Behavioral and Social Sciences and Education;" National.www.nap.edu. Copyright (C) National Academy of Sciences. All rights reserved. Education for Life and Work: Developing Transferable Knowledge and Skills in the 21st Century Janice Tripney, Title Registration For a Systematic Review: Post-Basic Technical and Vocational Education and Training (TVET) Interventions to Improve Employability and Employment of TVET Graduates in low- and Middle-income countries, The Campbell Collaboration | www.campbellcollaboration.org.

John Peet and Stephen Tindale, "The European Union budget 2014-20: More Boldness Needed,Centre for European Reform", Policy brief,2012,www. Kenneth M. Washer, and Srinivas Nippani. Human Capital and the Balance Sheet, Financial Counseling and Planning, Volume, 15 (1), 2004.

Kis, V. and E. Park (2012), "A Skills beyond School Review of Korea, OECD Reviews of Vocational Education and Training," OECD Publishing.

http://dx.doi.org/10.1787/9789264179806-en12.03.2016

Oecd,Factbook,2013,2012,preliminary version,

OECD, The High Cost of Low Educational Performance. LONG-RUN ECONOMIC IMPACTOF IMPROVING PISA OUTCOMES 2010,

Rafal Zelanzny, Information Society and Knowledge Economy, Journal of Economic and Management, vol.20 (2).2015

Safdari Mehdi, 2 Motiee Reza," Sources of Intellectual Capital and Investigating the Effects of Intellectual Capital on Economic Growth in Iran", Advances in Environmental Biology, 6(8): 2397-2402, 2012 ISSN 1995-0756, 2012

Europa,The online version of the leaflet The structure of the European education systems 2014/15: schematic diagrams can be found at: http://eacea.ec.europa.eu/education/eurydice/facts_and_f igures_en.php\#diagrams02,02.2016

Thomas Piketty, Capital- In The Twenty First Century, Harvard University press, 2014.

UIS Methodology For Estimation of means a years of Schooling, December, 2013 Unesco, Institute for Statistics, 2013

Unesco Institute for Statistic, Education Indicators Technical, Guidelines November, 2009

Yoo Jeung Joy Nam," Pre-Employment Skills Development Strategies in the OECD," Social Protection and Labor, the World Bank, 2009.

Wulong Gu and Ambrose Wong, Estimates of Human Capital in Canada: The Lifetime Income Approach, Catalogue no. 11F0027M — No. 062 ISSN 1703-0404 ISBN 978-1-100-14997-4,2010.

www.worldbank.org 